the structure of the CBFB gene, which is to be retracted in full.

Another 1995 paper in Molecular and Cellular Biology will also be fully retracted, while two more extensive studies published in the Proceedings of the National Academy of Sciences on the behaviour of CBFBSMMHC in vitro will be partially retracted, along with a fifth paper from the journal Genes, Chromosomes and Cancer.

When the problem with the figure in the sixth paper was brought to Collins' attention by the editors of Oncogene, it took him "about half an hour" to verify that it had been falsified, Collins says. There followed "two weeks of digging back" through laboratory records "collecting evidence that there had been systematic, long term fabrication" of results. The student admitted the fabrication, orally and in writing, Collins says.

Asked why he had not noticed the problem with the figure himself, Collins says

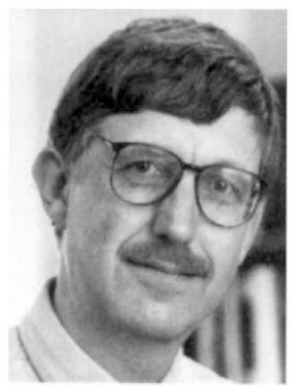

Collins: checking false figure took little time. he thinks that it is unusual for people to look at figures with a view to finding misrepresentation. "I may be doing more of that from now on," he says, adding that he is "intensely grateful" to the referce for noticing the problem.

As for the question of whether anyone can supervise a laboratory and run a large operation such as NCHGR at the same time, Collins says that he ran his lab there much the same way as he had done at the University of Michigan. Supervision of its work was "just too important to me" to neglect.

He said that it was "hard to know" how much time had been wasted by other scientists following the retracted work, but that "it wasn't a hot topic that everyone was jumping on".

But Ryan says that it is the loss of public trust, rather than the waste of research money, that scientists should be worrying about. He believes that fraud is much more widespread than the community admits.

Ryan wants a system of formal quality control, analogous to that used in industrial production,. introduced into federallyfunded laboratories. "I don't think enough is being done - and I've been beaten up pretty badly for saying so," says Ryan, referring to the community's hostile reaction to his commission's findings.

Even the severe critics of scientific conduct, however, congratulated Collins on his handling of this case once the fraud was detected. According to Walter Stewart, an outspoken critic of scientific misconduct who works at NIH, "on the facts as we know them now, the community owes him a great debt for doing the right thing in the most difficult of circumstances". Colin Macilwain

\title{
British ruling supports legal challenge to broad patents
}

London. Britain's House of Lords delivered its first legal judgement on genetic engineering patents last week, and gave a significant boost to the efforts of the European biotechnology industry to limit the breadth of protection that can be claimed for a single invention or discovery.

The move came as part of a decision by the Lords, which acts as Britain's highest legal authority, to uphold an appeal court decision invalidating a patent issued to Biogen Inc., based in Cambridge, Massachusetts, for a method of producing vaccines for hepatitis-B using genetically-engineered antigens.

The patent was based on research carried out by Kenneth Murray of the University of Edinburgh in the late 1970s. The immediate beneficiary of last week's decision is the British company Medeva, which plans to market its own hepatitis-B vaccine next year. Although this is based on a different genetic engineering technology, Medeva had been sued by Biogen for patent infringement.

But the decision has much broader implications, as it addresses what many in the biotechnology industry see as a major weakness in European patent legislation: the fact that, under the European Patent Convention, once a patent has been granted it cannot be challenged on the basis of the breadth of its claims.

Last year, the House of Commons select committee on science and technology, in its report on human genetics, recommended that the convention be "redrawn" to allow patents to be challenged on the grounds that their claims go too wide.

This proposal reflects a widespread view in the industry that, particularly in the early days of genetic engineering, several patents of questionable breadth were granted. One controversial example is the broad claim that has been granted to W. French Anderson and his colleagues in the United States for ex vivo techniques of gene therapy (see Nature 374, 393; 1995).

Attempts earlier this year by representatives of the biotechnology industry to persuade the European Patent Office, which is responsible for issuing Europe-wide patents under the convention, to change the rules on patent challenges were rebuffed.

But last week's ruling appears to move a substantial distance in this direction. Lord Hoffmann, the law Lord who wrote the ruling and is himself a former judge, appears to establish - at least under British law - that, even though the breadth of a patent claim is not explicitly listed as one of the aspects on which a patent can be challenged, questions of excessive breadth can nevertheless be used as the basis for mounting such a challenge.

Hoffmann emphasized in his ruling that care was needed "not to stifle further research and healthy competition by allowing the first person who had found a way of achieving an obviously desirable goal to monopolize every other way of doing it". And he added: "The Wright brothers had shown that heavier than air flight was possible, but that had not entitled them to a monopoly of heavier-than-air flying machines."

Gerald Kamstra, a patent attorney with the company Simmons and Simmons in London, says: "This decision goes some way to achieving what the industry has been seeking, at least in the United Kingdom."

Similarly, Nicholas Scott Ram, a senior executive with British Biotech and an adviser to the Bioindustry Association, the industry lobby group, welcomes what he calls "the right decision". Scott Ram adds: "It puts a handle on the question of the scope of a claim, and helps to ensure that the reward represented by a patent is commensurate with the work put into it."

The House of Lords' judgement effectively overturns an initial ruling by a patent judge that Medeva's technique for producing hepatitis-B antigens, although based on very different technology (including full knowledge of the genomic sequence of the virus, which was unknown at the time of Holmes' work), did indeed infringe the Biogen patent.

Medeva managed to have this ruling overturned by the Court of Appeal in 1994. The appeal court ruled that the patent was invalid both because the techniques that Murray had used to obtain hepatitis-B antigens using recombinant DNA technology were "obvious" at the time, and because the claims in the patent application, seeking the rights to all recombinant DNA molecules coding for hepatitis-B antigens, were too broad.

Biogen appealed against this ruling to the House of Lords, which upheld its claim that the techniques used by Murray were in fact novel enough to justify the patent. But the Lords also judged that the patent application had gone too far, and that as a result the patent was invalid.

A spokeswoman for Medeva - which acquired the rights to its own drug, currently in phase three clinical trials, from Swiss and German scientists in 1992 - welcomed what she described as a "decisive victory" for the company. Officials of Biogen said that the company was "clearly disappointed" by the decision, but would continue to collect royalties on British sales of its own vaccine.

David Dickson 